\title{
KÜLÖNÖS POLITIKATUDOMÁNY
}

\author{
Csepeli György \\ A recenzió beérkezett: 2020. március 27., véglegesítve: 2020. március 30.
}

(Szabó Márton: Diszkurzío politikatudomány. Bevezetés és a politika interpretativ szemléletébe és kutatásába. Budapest: Osiris Kiadó, 2016.)

Szabó Márton magisztrális múvét az Osiris Kiadó jelentette meg 2016-ban. A 693 oldalas könyv egészben mutatja meg Szabó Márton politikatudományi szemléletének radikalizmusát, újdonságát, és relevanciáját.

A mú újdonsága a diszkurzivitás középpontba állítása a politikai valóság megértésében, amiben az a felismerés tükröződik, hogy a politika valósága immanens módon tartalmazza a rávonatkozó interaktív értelmezéseket is. Ha ezt elfogadjuk, akkor a klasszikus, mainstream politikatudományi felfogáshoz képest egy jóval izgalmasabb, ha úgy tetszik titokzatosabb politikai világ tárul elénk, mely a politikai cselekvés kereteit kitágítva, mindenki esetében megengedi a politika valóságának megkonstrulásában való cselekvő részvételt. A politikai folyamatok értelemadás, értelemfejtés felöl történő vizsgálata megszünteti a megértést zsákutcába vezető „objektív-szubjektív"-dichotómiát, s egy olyan politikai valóság megmutatására ad lehetőséget a politika megértésére és magyarázatára vállalkozó tudós számára, mely "egyszerre objektív és szubjektív, és amelyet a politikai ágensek értelmező cselekedetek és cselekvő értelmezések révén közösen hoznak létre és tartanak múködésben" (19. o.). A mú hủen mutatja meg a diszkurzív politikatudomány újdonságát, bátorságát, és adekvációját a társadalmi valóságban konstruálódó, zajló, bomló és újraépülő politikai folyamatokhoz.

Miközben a diszkurziv politikatudomány szembenáll a mainstream pozitivista, strukturalista- funkcionalista politikatudomány elméleti pozícióival, a szembenállás soha nem éles. Ilyen értelemben mondható, hogy Szabó Márton „szelid politológus”, aki azonban következetes és elszánt a maga által „alternatív szemléletư"'-nek nevezett politikatudomány kialakításában (Csepeli, 2014). Könyve meggyőzően mutatja, hogy a szerző milyen következetesen épitkezik fejezetről fejezetre előre haladva a diszkurzivitás értelmező tereibe beállított politikai valóság tényeinek bemutatásában, melyet a szereplők, az ügyek, a kutatások és mindezek beteteződéseként a politológiák tárgyalása követ.

A könyv újdonsága az episztemológiai részben bontakozik ki igazán, melynek első fejezetében a szerző a politikai tény sajátosságainak meghatározási 
lehetőségeit keresi. Fontos megkülönböztetés, hogy a politikai tény és a politológia által politikainak tartott tény nem azonos. Utóbbit a tudományos praxis termeli ki, melynek jól ismert szakaszai a szelektálás, gyưjtés, feldolgozás, kiértékelés. Az alapvető tényekre épülnek további tények, amelyek együttese teszi lehetôvé a politikai folyamatok elemzését. Mindez a mindenkori jelenben zajlik, ami miatt a már elmúlt jelenben született politológiai elemzések politológiai szempontból oly érdektelenek, mint a tegnapi újság. A múltnak nincs politológiája. A múlt politikai tényeinek vizsgálatában a politológus helyét a történész veszi át.

A diszkurzivitás nemcsak a politika valóságát hatja át, hanem kiiktathatlanul jelen van a politikai valóság politikatudományi rekonstrukciójában. Szabó Márton érzékenyen különbséget tesz a "felfedező" és a "feltáró" politikatudós között, többszörös reprezentációról beszél a politikai ember, a megfigyelő ember, a kutató ember és a közlő ember között. Kár, hogy csak egy mellékmondatban szól a politológiai tudás hatalomhoz való kötődésének különféle szintjeiről és módozatairól, melyeket eufemésztikusan mint "kínokat” jellemez (42. odal). A diszkurzivitás mint módszertani kiindulás nyilván nemcsak a politika valóságára, hanem a politika valóságának megszólaltatására is érvényes, ezért szívesen olvastunk volna többet arról, hogy a diszkurzivitás miként van jelen az egyes politikatudósok egymásközti kommunikáciájában és miként járulhat hozza a politológiai tudás hatalomhoz való kötődésével együttjáró kínok enyhítéséhez.

A jelek és a jelentések diszkurzív viharában a nyelv kitüntetett helyet foglal el. Heideggert parafrazeálva mondhatjuk, hogy a nyelv a politikai lét háza, melynek téglái az élő majd leírt szövegek szavai. Szabó Márton az egymással versengő diskurzuselméletek között biztos kézzel jelöli ki a maga elméletének helyét, a szövegegészekben jelölve meg a politikai hermeneutika tárgyát. A következőkben a megszólalók beszédére összpontosít, azokat Austin beszédaktus elméletéhez visszanyúlva cselekvésként azonosítva. A nyelv ezen a ponton túlmegy önmagán, s cselekvéssé válik, mely a politikai dráma éltetője és kelesztője. Nagyon fontos, amit a szerző a nem cselekvés, a nem kimondás cselekvés értékéről ír. A szerző leleményesen alkalmazza a politikai életre a kommunikáció szociálpszichológiájából jól ismert igazságot, miszerint az emberek nem tudnak nem kommunikálni, s ez nem lehet másként a cselekvéseket politikailag meghatározó kontextusokban sem.

A nyelven kívüli világ a politikai jelentések erőterébe kerülve messzemenően alkalmas politikai folyamatok és jelenségek generálására. Ezt a szerző a politikai szimbólumok példáján bizonyítja, melyek vizsgálata korai politikatudományi munkásságának egyik kiemelkedően jelentős állomása volt.

Az episztemológiai rész második fejezete a politikatudományi megismerés kulcskérdéseit veszi szemügyre, eredeti és eruditív módon. A szerző konstruktivista, hermeneutikai felfogásához híven abból indul ki, hogy mint a gyöngy- 
halász a mély vízbe, a megismerő aktív módon merül le a megismerni kívánt valóságba, annak a mélyéből a felszinre hozva vizsgálatának tárgyait. Ezután következik a szelekció, az értékelés, a kontextualizálás, a tudományos szövegbe foglalás.

A gyöngy, amit a politológus megtalált a mélyben, s felszínre hozva vizsgál, a létezés és megismerés egységében fogant politikai tény, mely nem befejezett, sem nem objektív, sem nem szubjektív. A politikai tény Szabó Márton felfogásában a múló idő pillanatához kötött, adott térben, helyzetben létező gyakorlat, melynek izgalma onnan való, hogy az érdelődő megismerő számára kinyítja az értelmezések Pandóra szelencéjét. A politikatudós számára a tények versengő értelmezések kiindulópontjai, melyek sokféle irányban, sokféle módon kapcsolódnak a további tényekhez.

Az értelmezések sokfélesége azért van, mert a tény sosem csak egy jelenben zajló, befejezett esemény, hanem a jövőben lehetséges történések hordozója is, amit Bismarck zseniálisan úgy jellemez, hogy a politika a lehetőségek feltárása („Die Politik ist die Lehre von Möglichkeiten”).

A politikatudomány sem adhatja ennél alább. Minden egyes politikai tény esetében az elemzőnek el kell indulnia a bismarcki nyomon, feltárva, hogy egy-egy politikai tény létrejövésében milyen szerepet játszottak a lehetőségeket a lehetetlen és a szükségszerü között megjelenítő valószínűségek, melyeket a politikai cselekvők távolról sem mindig pontosan látnak. Együtt kavarog bennük a csodavárás, a kishitûség, a meglepetés, az alkalomra való ráérzés. Mindez a nyelv varázslatai révén áll elő a politikai tény nyitott valóságában, mint azt a szerző gazdag szakirodalmi anyagon, Max Weber, Ricoeur, Kosselleck és Gadamer gondolataira támaszkodva kifejti.

A nyitott, befejezetlen politikai tények csak utólag, lezajlásukat, bekövetkezésüket követően válnak a szó konvencionális értelmében tényekké, de keletkezésük idején, valószínűségekként elválaszthatatlan elemük a fikció, amely ha erős a lelkeket megmozgató ígéret, akkor utóbb valóság lesz, további tények kiindulópontja. A politikai tényektől elválasztatlan nyelvi burok szükségképpen magával hozza a szűntelen dialogizálást, mely a megértő-magyarázó értelem számára szüli az elemzendô anyagot.

Módszertanilag mindebből az a radikális következtetés adódik, miszerint a fogalmak ideális világába zárt elemzés terméketlen, mint Goethe mondja, "fakó minden teória, s a lét aranyló fája zöld". A megoldást Szabó Márton Lukács György „különös” esztétikai kategóriájában látja, melynek politikatudományi megfelelője a kivétel, a rendkívüli. A lét a kivétel által ütött hasadékon keresztül válik láthatóvá, miközben megtartja diszkurzív, dialogikus természetét. Ezen a meredek úton a kapaszkodást Kierkegaard, Walter Benjamin, Carl Schmitt segíti a szerzőnek.

Az első rész harmadik nagy egysége, amely a politikai tényekkel és a politikai megismerésekkel megkezdett úton tovább kalauzolja az olvasót a disz- 
kurzív politikatudomány útján, a politikai történések kereteivel, az intézményekkel, a szervezetekkel foglalkozik. Az intézményeket és a szervezeteket a szakirodalmi kánon szerint meghatározva Szabó szabályszerúen visszatérő interakciók mintázataiként írja le. Szakirodalmi előzményként szóba kerül G. W. Sumner kissé kusza, de mindmáig megkerülhetetlen múve a jogi és egyéb népszokásokról, amelyek a kezdeti emberi csoportok számára tették lehetővé a rendezett, anticipálható kollektív cselekvést. Szabó Márton politikatudománya szempontjából az intézmények diszkurzív megközelítése a járható út, amely kiemeli a konstruktivitást, az ágensek aktivitását, tágra nyitja mozgási körüket. A megismerés és az általánosítás poblémájának megoldására, úgy tûnik az intézmények esetében, akár csak a politikai tények esetében, a megismerésre, a megismerés eredményeként lehetséges általánosításra a kivételes állapot bekövetkezése, a szabályszerűség felrugása ad alkalmat. Jó szempont, hogy diszkurzív intézményesedés a politikában a fennmaradás, a fenntartás érdekében a jelentéses környezet folyamatos teremtését jelenti, amiben az egyéni tetteknek kitüntetett szerep jut.

Itt tér át a szerző a szervezetekre, amelyeket Max Weber nyomán a racionális kollektív cselekvés színtereiként jellemez, kiemelve a környezet és a benne élő, múködő szervezet struktúrája közötti kontingenciákat. Igen érdekes és eredeti a szervezetek evolúciós elvek szerinti magyarázata, bár a biológiai evolúcióval való összevetés nem problémátlan, hiszen az utóbbi a gének által történő információ átadása révén írja le a populációk egyedeinek átörökítődését és az esetleges mutációkat, míg a szervezetek esetében a szervezetspecifikus mémeknek juthat hasonló szerep. A diszkurzív szemléletból logikusan adódik, hogy a szerző az interpretatív szervezetfelfogás mellett teszi le a garast, amely konstruktivista, kommunikatív, életszerú és természetes. A politikai szervezetek sorában az állam és a párt kerül a szerző látókörébe, mindkettőt a nyilvános diszkurzív térbe helyezve láttatja, ahol a résztvevők interakciói múködtetik a szervezet valóságát. Itt érdemes lett volna kitérni a politikai mozgalmakra, melyekben a később kifejlődő szervezetek csírái vannak.

A könyv további fejezetei közül két fejezet mindképpen megemlítendő, mert azok nélkül a teljes rendszer csonka lenne. Az egyik ilyen fontos fejezet a politikai színtér szereplőivel foglalkozik, akiket Carl Schmitt alapján a szerző az ellenség-barát-tengely mentén osztályoz, s ebból vezeti le a további kategóriákat, a szövetségeseket, az ellenfeleket, az állampolgárokat, s az idegeneket. A másik fontos fejezet a politikai ügyeket veszi szemügyre, amelyek a politikai tevékenység középpontjában vanak.

A diszkurzív politikatudomány egészével foglalkozó monumentális mú további fejezete a politikai tevékenységet szolgáló kutatásokkal foglalkozik. A politikai folyamatokat leíró, magyarázó, megértető politológiákat tárgyaló fejezet nem epilógus, a szerző módszeréhez híven nem lezárja, hanem kinyítja 
a további gondolkodás felé vezető utat, melynek végén már az autentikus politikatudományt látjuk.

A szerző politikatudományi felfogása eredendően interdiszciplináris, nyitott a filozófiai antropológia, a fenomenológia, a szociálpszichológia és a kulturális antropológia irányaiban. A nyitottság azonban csak kapcsolódás, mely sosem fenyeget a sui generis politikatudományi perspektíva elvesztésével. Ezzel kapcsolatban a szociálpszichológus recenzens kritikaként megfogalmazhatja, hogy a politikatudomány diszkurzív fordulatát a szerző nem ágyazza be a társadalomtudományok korábban megkezdődött fenomenológiai, interpretatív változásaiba, melyek előzményei a szociálpszichológiában, G. H. Mead szimbolikus interakcionizmusa, E. Gofman dramaturgiai szociálpszichológiája, H. Garfinkel etnometodológája, A. Cicourel kognitív szociológiája. Ugyancsak érdemes lett volna kitekinteni a politikai antropológia bölcsőjét hajdan ringató kulturális antropológiára, melynek interpretativ változatát Mary Douglas oly magas fokon múvelte. Szabó Márton a politikát mint drámát állítja elénk, amely a maga erejével diszkurziv, konstruált, kontingens létezésmódjánál fogva minden más, emberek közötti konfliktusos létmód archetípusa lehetne. Ebben az értelmezésben nagy segítség lehetne Victor Turner leírása a rituális folyamatról, amelynek fázisai a megszegés, a krizis, a jóvátétel és a reintegráció.

A szervezetekről és az intézményekről szóló részben a szerző utalhatott volna a Gervase R. Bushe és Robert J. Marshak nevéhez füződő, a szervezetszociológiában úttörő dialogikus szervezetfejlődés elméletére, mely a szervezeti változást a diszkruzív politikatudomány felfogásával maximálisan megegyezve a szervezeteket dialogikus rendszerekként jeleníti meg. E rendszerekben az egyéni és kollektív cselekvések önszervező, társadalmilag konstruált valóságot hoznak létre, melyeket narratívák, történetek, társalgások, jelentéstulajdonító gyakorlatok múködtetnek és tartanak fenn.

A könyv olvasása során a recenzensben felvetődött a gondolat, hogy a politikai folyamatok leírása, értelmezése, hermeneutikai tartalmaik megfejtése szükségképpen időhöz kötött, a mindenkori jelen nolens volens múlttá válik, ami felveti azt a kérdést, hogy hol ér véget a diszkurzív politikatudomány, s hol kell átadja helyét a mikro- és pszichohistóriának, amelynek tudósai a politikatudós problémáihoz teljesen hasonló problémákkal kell hogy szembenézzennek.

Nem bírálat, inkább kérdés, hogy a szerző miként nézne szembe a könyv lezárását követő, a politikai tényeket és folyamatokat is mélyrehatóan érintő infokommunikációs technológiai változásokkal, amelyek következményeként a Heidegger által zseniálisan machinációként megsejtett adatalapú beavatkozások a diszkurzivitás lényegéhez tartozó szabadságot kiiktatják a politikai ágensek egymásközti viszonyaiból. Érdekelne bennünket, hogy a szerző azokkal ért-e egyet, akik e változásokat pesszimistán, a totális ellenőrzés lehetséges megvalósulásaként nézik, mint Shoshana Zuboff legutóbb megjelent mú- 
vében, vagy inkább optimista-e, s az ellenállás lehetôségét is látja, mint Henry Timms és Jeremy Heimans.

Hankiss Elemér utolsó, életében már meg nem jelent írásában veti fel, hogy az emberi életről való gondolkodás, melynek része a politikáról való gondolkodás is, a kvantummechanika által megnyított világon át vezet a teljességhez. A Higgs-mezőn túl rejtőzködő ismeretlen és végtelen tartományról írva azt kérdezi; „képtelenség feltételezni azt, hogy ebben a távoli és ismeretlen tartományban a kvantumfizika és a filozófia találkozik, akárcsak a párhuzamosok a végtelenben?" (Hankiss, 2018).

A szerző hatalmas kockázatot vállalt azáltal, hogy két évtizede kilépett a politikatudományi folyóiratok, társaságok, tanszékek által politikatudományként azonosított elméleti és módszertani keretekből, s egy alternatív, a politológiát és a politikát immanens egységben tartó politikatudomány megalapozásába kezdett. A kockázat a recenzens nézete szerint abban van, hogy a politika Szabó Márton által kidolgozott új elmélete nem állhat meg magában. Az új politikaelmélet új lét- és társadalomelméletet feltételez, amelynek megírása még várat magára. Mindent összevetve hálásak lehetünk Szabó Mártonnak, hogy olyan múvet alkotott, amelynek előfeltevéseit, módszertanát, eredményeit következetesen végig gondolva eljuthatunk Hankiss Elemér csodálatos kérdéséig.

\section{IRODALOM}

Csepeli György (2014): A szelíd politológus (Szabó Márton: Kötőjelek. Budapest, L'Harmattan Kiadó). Jog - Állam - Politika, VI. évf. 2014 évi 3. szám, 157-159.

Hankiss Elemér (2018): Kvantummechanika és az élet értelme. Magyar Tudomány, 179., 10., 15811591

Zuboff, Shoshana (2019): The age of surveillance capitalism

Timms, Henry-Heimans, Jeremy (2018): New Power: How It's Changing the 21st Century - and Why You Need to Know. 